\title{
ANALISIS FINANCIAL DISTRESS PADA PERUSAHAAN BATUBARA YANG TERDAFTAR DI BURSA EFEK INDONESIA PERIODE 2011 - 2014
}

\author{
Tiodorma Br. Sijabat \\ Alumni Jurusan Manajemen Fakultas Ekonomi Universitas Negeri Medan \\ Cut Ermiati \\ Dosen Jurusan Manajemen Fakultas Ekonomi Universitas Negeri Medan
}

\begin{abstract}
Abstrack
The purpose of this study was to determine whether the financial ratios in Altman can explain financial distress. There are five financial ratios in Altman, which is the ratio of Net Working Capital to Total Assets $\left(X_{1}\right)$, Retained Earnings to Total Assets $\left(X_{2}\right)$, Earnings Before Interest and Tax to Total Assets $\left(X_{3}\right)$, Market Value of Equity to Book Value of Total Debt $\left(X_{4}\right)$ and Sales to Total Assets $\left(X_{5}\right)$. The population in this study are listed coal company in Indonesia Stock Exchange period 2011 - 2014. This study used purposive sampling method of sampling so that there are 18 companies. The data used is secondary data that is accessed from the website www.idx.co.id. The analytical method used is descriptive analysis. The results of this study for five years of observation, the financial ratios in Altman can explain financial distress in the coal company listed on the Indonesia Stock Exchange. The coal company in this study more companies to financial distress or equivalent to $56.67 \%$ of the company. Where it can be seen from the decline in corporate earnings and some have suffered losses in recent years, the decline in the sales of the company, the amount of the costs the company the amount of debt continues to rise and stock prices continue to fall in the capital market.
\end{abstract}

Keywords: Financial Ratios, Altman Z-Score Model, Financial Distress

\section{PENDAHULUAN}

Indonesia merupakan salah satu penghasil batubara terbesar didunia. Hal tersebut pula yang membuat Indonesia menjadi salah satu produsen dan eksportir terbesar batubara yang diperhitungkan internasional. Namun sepanjang tahun 2015 perkembangan industri batubara menjadi fokus dalam dunia usaha karena kinerja dari perusahaan batubara mengalami penurunan. Penurunan kinerja perusahaan batubara disebabkan perlambatan pertumbuhan ekonomi di Negara China serta didukung dengan menurunnya harga jual batubara.

Perlambatan pertumbuhan ekonomi China yang dimana China merupakan negara dengan ekonomi terbesar kedua di dunia tersebut adalah mitra dagang yang paling penting bagi Indonesia tetapi sekarang membawa dampak negatif. Dampak negatif tersebut adalah menurunnya nilai ekspor produk batubara Indonesia karena kebijakan baru China, yaitu pembatasan impor batubara berkalori terendah(http://www.batamtoday.com /berita45373-Industri-Batubara-CinaMelemah,-Berpotensi-RugikanIndonesia.html). Selain itu, China sebagai konsumen energi terbesar dunia sedang berupaya mengurangi intensitas penggunaan energi yang berdampak pada pengurangan penggunaan batubara. Kebijakan pembatasan impor batubara berkalori rendah ini dilakukan karena 
JURNAL PLANS

Penelitian Ilmu Manajemen \& Bisnis

ISSN: $1978-7057$

E-ISSN: 2527-306X

China ingin menjaga kelestarian

lingkungan.

Tabel 1.Konsumsi Batubara 2009 - 2015

\begin{tabular}{lccccccc}
\multicolumn{1}{c}{ Keterangan } & $\mathbf{2 0 0 9}$ & $\mathbf{2 0 1 0}$ & $\mathbf{2 0 1 1}$ & $\mathbf{2 0 1 2}$ & $\mathbf{2 0 1 3}$ & $\mathbf{2 0 1 4}$ & $\mathbf{2 0 1 5}$ \\
\hline Produksi (Juta Ton) & 254 & 275 & 353 & 412 & 474 & 458 & 376 \\
Ekspor (Juta Ton) & 198 & 210 & 287 & 345 & 402 & 382 & 296 \\
Penjualan Domestik (Juta Ton) & 56 & 65 & 66 & 67 & 72 & 76 & 80 \\
$\begin{array}{l}\text { Harga Rata-Rata Batubata Menurut } \\
\text { HBA (USD/Ton) }\end{array}$ & 70.7 & 91.7 & 118.4 & 95.5 & 82.9 & 72.6 & 60.1 \\
\hline
\end{tabular}

Sumber: Asosiasi Pengusaha Batubara Indonesia (APBI) dan Direktorat Mineral dan Batubara Kementerian ESDM RI

Dari tabel menunjukkan

bahwa ekspor batubara pada tahun 2009 hingga tahun 2013 terus mengalami kenaikan hingga mencapai angka 402 juta ton dan dari tahun 2014 dan 2015 mengalami penurunan yang mencapai angka 296 juta ton. Penurunan ini diakibatkan karena adanya kebijakan baru dari China yang mengurangi pasokan energi yang berdampak pada penurunan jumlah ekspor batubara di China. Selain itu, masalah selanjutnya yaitu mengenai Harga Batubara Acuan (HBA) yang terus mengalami penurunan dari tahun 2011 sampai 2015 hingga mencapai nilai 60.1 USD/ton yang dimana pada tahun 2009 seharga 70.7 USD/ton hingga tahun 2010 terus

mengalami peningkatan harga mencapai nilai 118.4USD/ton.

Menurunnya harga jual batubara merupakan akibat dari kelebihan penawaran dan kelebihab kapasitas di pasar. Kelebihan penawaran di pasar China membuat permintaan batubara menurun sebanyak 20 juta ton pada tahun 2014, dan pada tahun 2015 permintaan tersebut turun sebanyak 66 juta ton dari tahun sebelumnya. Hingga pada Bulan Maret 2015, kisaran harga batubara sekitar 51.62 USD/ton. Gambar dibawah ini menunjukkan Harga Batubara Acuan (HBA) dan Harga Patokan Batubara (HPB) terus mengalami penurunan selama tahun 2011 hingga awal tahun 2016.

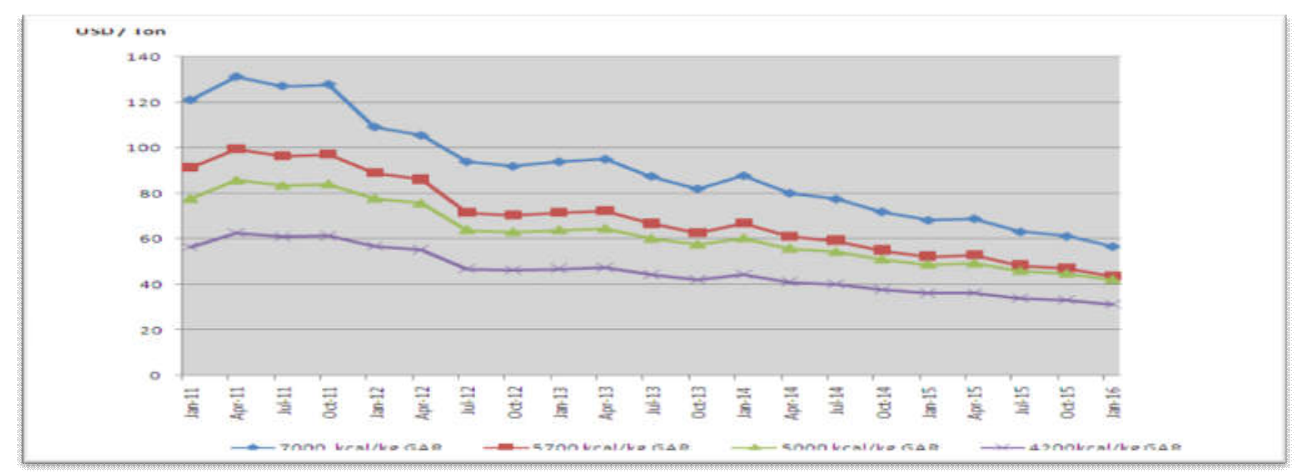

Gambar 1. Perkembangan HBA dan HPA Januari 2011 - Januari 2016 
Sumber: Direktorat Mineral dan Batubara Kementrian ESDM RI

Dari gambar 1 dapat kita lihat

bahwa harga batubara mengalami fluktuasi tetapi tren yang tampak jelas dari gambar adalah harga batubara mengalami penurunan setiap tahunnya mulai dari Januari 2011 sampai pada awal tahun 2016. Menurunnya HBA yang terjadi secara terus-menerus dapat berdampak pada menurunnya pendapatan industri batubara. Dengan pendapatan yangmenurun dan biaya produksi yang tetap besar hal tersebut akan berakibat pada net incomeperusahaan. Dalam kondisi ini perusahaan tidak dapat memaksimalkan keuntungan, bahkan terdapat kemungkinan perusahaan akan memilikinet incomenegatif yang berarti perusahaan sedang mengalami kerugian. Kerugian yang terjadi akibat penurunan HBA dapat mengakibatkan perusahaan mengalami kesulitan keuangan (financial distress). Kemungkinan terburuk apabila perusahaan tidak dapat menyelesaikan kesulitan finansial yang dialami maka perusahaan akan mengalami kebangkrutan sehingga perusahaan harus dilikuidasi. Selain itu perusahaan tidak dapat melakukan bertanggung jawab penuh kepada para stakeholderdalam bentuk pembagian deviden.

Kinerja perusahaan dalam kegiatan operasi tercermin dalam laporan keuangan tahunan yang mengandung informasi akuntansi mengenai kondisi perusahaan. Dari informasi akuntansi tersebut dapat diketahui likuiditas, profitabilitas, leveragehingga aliran arus kas perusahaan. Dengan demikian informasi akuntansi yang terkandung didalamnya dapat dijadikan sebagai bahan pertimbangan oleh para investor dan kreditor. Untuk itu informasi akuntansi harus dapat diandalkan dan relevan dengan kondisi yang sesungguhnya sehingga mampu menggambarkan kemungkinan yang akan terjadi masa yang akan datang. Dengan informasi akuntansi yang terkandung dalamnya, laporan keuangan dapat mengidentifikasi kondisi financial distresspada sebuah perusahaan.

Tabel 2. Rasio Pertumbuhan Perusahaan Batubara Tahun 2014

\begin{tabular}{lcccc}
\hline \multicolumn{1}{c}{ Perusahaan } & Laba / Rugi & Pertumbuhan & Pendapatan & Pertumbuhan \\
\hline Adaro Energy & USD 183.5 miliar & $21 \%$ & USD 3.33 miliar & $1 \%$ \\
Bumi Resources & USD -465.9 miliar & $-171 \%$ & USD 2.79 triliun & $-21 \%$ \\
Bayan Resources & USD - 189 juta & $-442 \%$ & USD 828.3 juta & $-28 \%$ \\
Golden Energy Mines & IDR 133.8 miliar & $-56 \%$ & IDR 5.2 triliun & $18 \%$ \\
Harum Energy & USD 2.6 juta & $-95 \%$ & USD 477.6 juta & $-43 \%$ \\
Indo Tambang Raya Megah & USD 200.2 juta & $-2 \%$ & USD 1.9 miliar & $-14 \%$ \\
Resorce Alam Indonesia & USD 8 juta & $-53 \%$ & USD 135.8 juta & $-30 \%$ \\
Samindo Resources & IDR 268.3 miliar & $54 \%$ & IDR 3.02 triliun & $23 \%$ \\
Bukit Asam & IDR 2.01 triliun & $9 \%$ & IDR 13.07 triliun & $17 \%$ \\
Petrosea & USD 2.2 juta & $-87 \%$ & USD 347.9 juta & $-3 \%$ \\
Golden Eagle Energy & USD -3.5 miliar & $-118 \%$ & USD 20.92 miliar & $-41 \%$ \\
Toba Bara Sejahtera & USD 35.8 juta & $3 \%$ & USD 499.9 juta & $19 \%$ \\
\hline Sumber: Bursa Efek Indonesia (Data diolah) & \multicolumn{4}{c}{} \\
\multicolumn{7}{c}{ Tabel diatas } & menjelaskan & penurunan & pertumbuhan pada laba \\
bahwa dari beberapa & perusahaan & bersihnya. & Penurunan pertumbuhan \\
batubara yang terdaftar di Bursa Efek & laba bersih paling besar terjadi pada \\
Indonesia (BEI) rata - rata mengalami & perusahaan Bayan Resources yaitu -
\end{tabular}


$442 \%$ yang dimana penurunannya menjadi -189 juta di tahun 2014. Berbeda dengan perusahaan Samindo Resources yang mengalami kenaikan pertumbuhan sebesar $54 \%$ dengan laba bersih 268.3 miliar di tahun 2014.

Bukan hanya masalah perlambatan ekonomi China dan menurunnya harga batubara yang sedang dialami oleh perusahaan batubara. Tetapi juga masalah tentang kebijakan smelter yang dikeluarkan oleh pemerintah. Kebijakan Smelter merupakan aturan ekspor batubara yang dikeluarkan pemerintah, aturan tersebut berupa larangan ekspor bahan mentah tambang mineral, batubara, dan gas yang tertulis dalam UU No. 4 Tahun 2009 namun baru akan diberlakukan mulai 2014. Sebelum larangan itu diterapkan, pemerintah akan mengenakan pajak ekspor $15-50 \%$ guna mengendalikan eksploitasi sumber daya alam secara besar-besaran.

Smelter itu sendiri adalah sebuah fasilitas pengolahan hasil tambang yang berfungsi meningkatkan kandungan logam seperti timah, nikel, tembaga, emas, dan perak hingga mencapai tingkat yang memenuhi standar sebagai bahan baku produk akhir. Proses tersebut telah meliputi pembersihan mineral logam dari pengotor dan pemurnian. Pembangunan Smelter diwajibkan bagi seluruh perusahaan tambang di Indonesia, baik bagi perusahaan besar maupun kecil.

Apabila masalah ini terus terjadi terus - menerus maka perusahaan akan mengalami masalah keuangan (financial distress). Seperti yang telah dipaparkan diatas bahwa perusahaan batubara sedang mengalami krisis dalam melakukan kegiatan operasionalnya yang terlihat dari pertumbuhan perusahaan yang mengalami penurunan. Apabila kondisi financial distress ini terjadi secara berkelanjutan setiap tahunnya, maka akan membuat para pemegang saham tidak akan memberikan kepercayaan pada perusahaan tersebut.

Pihak manajemen perusahaan sangat penting dalam memperhatikan keuangan perusahaannya. Salah satunya adalah apabila laba bersih yang dihasilkan tidak sebanding dengan biaya yang telah dikeluarkan oleh perusahaan. Dan lagi, apabila perusahaan memperoleh pendapatan atau penjualan yang besar tetapi laba bersihnya kecil bahkan mengalami kerugian. Hal ini merupakan tanda bahwa perusahaan sedang mengalami kondisi financial distress. Maka dari itu perusahaan perlu melihat bagaimana kinerja keuangan perusahaannya, seperti rasio-rasio keuangan perusahaan sebagai salah satu cara untuk mengatasi kondisi financial distress pada perusahaan.

Ada beberapa model yang dapat memprediksi kondisi financial distress untuk melihat rasio-rasio keuangan perusahaan seperti Model Altman, Model Zmijewski, Model Springate, Model Foster, Model Ohlon, dan Model Fulmer. Tetapi pada penelitian ini penulis menggunakan model Altman. Model Altman merupakan model dalam memprediksi kondisi financial distress yang diciptakan pertama kali dengan tingkat keakuratan yang tinggi yaitu sebesar 95\%. Selain itu Model Z-Score Altman merupakan model yang mengalami revisi sebagai bentuk penyempurnaan. Revisi tersebut 
dimaksudkanagar model prediksi dapat digunakan pada semua jenis perusaahaan seperti manufaktur, non manufaktur, dan perusahaan keuangan baik perusahaan swasta maupun go public.

Analisis yang digunakan pada model Altman mengacu pada rasio rasio keuangan perusahaan. Rasio menggambarkan suatu hubungan antara suatu jumlah tertentu dengan jumlah yang lainnya. Dengan menggunakan alat analisis berupa rasio ini akan dapat menjelaskan atau member gambaran bagaimana keadaan keuangan perusahaan tersebut. Rasio-rasio keuangan yang yang digunakan dalam model Z-Score (Altman) antara lain: Working Capital to Total Asset, Retained Earning to Total Asset, Earning before Interest and Taxes to Total Asset dan Market Value of Equity to Book Value of Liability.

\section{FINANCIAL DISTRESS}

Financial distress adalah kondisi yang menggambarkan keadaan sebuah perusahaan yang sedang mengalami kesulitan keuangan, artinya perusahaan berada dalam posisi yang tidak aman dari ancaman kebangkrutan atau kegagalan pada usaha perusahaan tersebut. Emrinaldi (2007) menyatakan kondisi yang paling mudah dilihat dari perusahaan yang mengalami financial distress adalah pelanggaran komitmen pembayaran hutang diiringi dengan penghilangan pembayaran dividen terhadap investor. Namun, menurut Whitaker (1999), financial distress terjadi saat arus kas perusahaan kurang dari jumlah porsi hutang jangka panjang yang telah jatuh tempo. Intinya, financial distress terjadi ketika perusahaan mengalami kesulitan kepuangan yang dapat diakibatkan oleh berbagai macam akibat.

Salah satu penyebab kesulitan keuangan menurut Brigham dan Daves (dalam Anggarini, 2010) adalah adanya serangkaian kesalahan pengambilan keputusan yang tidak tepat, dan kelemahan - kelemahan yang saling berhubungan yang dapat menyumbang secara langsung maupun tidak langsung kepada manajemen serta tidak adanya atau kurangnya upaya mengawasi kondisi keuangan sehingga penggunaan uang tidak sesuai dengan keperluan. Hal ini memberikan kesimpulan bahwa perusahaan besar tidak menjamin dapat menghindari masalah ini, sebab financial distress berkaitan dengan keuangan perusahaan dimana setiap perusahan pasti akan berurusan dengan keuangan untuk menjaga kelangsungan operasinya.

\section{PENILAIAN FINANCIAL DISTRESS MENGGUNAKAN MODEL ALTMAN Z-SCORE}

Analisis diskriminan Altman merupakan salah satu teknik statistik yang bisa digunakan untuk memprediksi adanya kebangkrutan suatu perusahaan. Altman telah mengkombinasikan beberapa rasio menjadi model prediksi dengan teknik statistik. Menurut Supardi (2003:11) Altman adalah diskriminan yang digunakan untuk mempredikasi kebangkrutan perusahaan dengan istilah yang sangat terkenal yang disebut $Z$ Score.

\section{Model Altman Pertama}

Z-Score adalah skor yang ditentukan dari perhitungan rasio keuangan yang menunjukkan tingkat kemungkinan kebangkrutan 
perusahaan (Ramadhani, 2009). Formulanya adalah sebagai berikut:

$Z=1,2 X 1+1,4 X 2+3,3 X 3+0,6 X 4+0,999 X 5$

Keterangan:

$\mathrm{Z}=$ bankruptcy index

$\mathrm{X} 1=$ working capital / total assets

$\mathrm{X} 2=$ retained earnings / total assets

$\mathrm{X} 3=$ earnings before interest and

taxes / total assets

$\mathrm{X} 4=$ market value of equity / book value of debt

$\mathrm{X} 5=$ sales $/$ total assets

Dari hasil perhitungan model Altman diperoleh nilai Z-Score yang dibagi dalam tiga kategori sebagai berikut:

a. Jika nilai $\mathrm{Z}>2,99$ maka perusahaan termasuk dalam kategori tidak bangkrut.

b. Jika nilai $1,80<\mathrm{Z}<2,99$ maka perusahaan termasuk dalam kategori grey area (tidak dapat ditentukan apakah perusahaan mengalami kebangkrutan atau tidak).

c. Jika nilai $\mathrm{Z}<1,80$ maka perusahaan termasuk dalam kategori perusahaan yang bangkrut.

\section{Model Altman Revisi}

Model yang dikembangkan oleh Edward I. Altman pada tahun 1968 mengalami suatu revisi pada tahun 1983. Model ini mampu untuk memprediksi financial distressed dengan ketepatan 95 $\%$. Revisi yang dilakukan merupakan penyesuaian yang dilakukan agar model prediksi kebnagkrutan ini tidak hanya diaplikasikan untuk perusahaan yang go public, melainkan juga dapat diaplikasikan untuk perusahaanperusahaan yang tidak go public. Model tersebut mengalami perubahan pada satu variable yaitu $\mathrm{X} 4$ di mana market value of equity dirubah menjadi book value of equity, sehingga model revisinya menjadi sebagai berikut (Ramadhani,2009):
$Z=0,717 X 1+0,84 X 2+3,108 X 3+0,41 X 4+0,99 \times 5$

Keterangan:

$\mathrm{Z}=$ bankcruptcy index

$\mathrm{X} 1=$ working capital/total assets

$\mathrm{X} 2=$ retained earnings/total assets

$\mathrm{X} 3=$ earning before interest and taxes / total asset

$\mathrm{X} 4$ = book value of equity/book value of debt

$\mathrm{X} 5=$ sales/total assets

Dari hasil perhitungan Model Altman Revisi diperoleh nilai Z-Score yang dibagi dalam tiga kategori sebagai berikut:

a. Jika nilai $\mathrm{Z}>2,90$ maka perusahaan termasuk dalam kategori tidak bangkrut.

b. Jika nilai $1,23<Z>2,90$ maka termasuk grey area atau dinyatakan kristis (tidak dapat ditentukan apakah perusahaan sehat ataupun mengalami kebangkrutan)

c. Jika nilai $\mathrm{Z}<1,23$ maka perusahaan termasuk dalam kategori bangkrut.

\section{Model Altman Modifikasi}

Model yang dikembangkan oleh Edward I. Altman pada tahun 1983 mengalami suatu modifikasi pada tahun 1995. Altman melakukan modifikasi model untuk meminimalisir efek industri karena keberadaan variabel perputaran aset (X5). Dengan model yang dimodifikasi, model Altman dapat diterapkan pada semua perusahaan baik perusahaan manufaktur maupun perusahaan non manufaktur. Dalam model Altman Modifikasi, Altman mengeleminasi variabel X5, yaitu rasio penjualan tetap total aset, sehingga model modifikasinya menjadi sebagai berikut (Ramadhani, 2009):

$Z=6,56 X 1+3,26 X 2+6,72 X 3+1,05 X 4$

Keterangan:

$\mathrm{Z}=$ bankcruptcyindex

$\mathrm{X} 1=$ working capital/total assets

$\mathrm{X} 2=$ retained earnings/total assets

$\mathrm{X} 3=$ earning before interest and taxes/total assets 
$\mathrm{X} 4$ = book value of equity/book value of total debt

Dari hasil perhitungan Model Altman Modifikasi diperoleh nilai ZScore yang dibagi dalam tiga kategori sebagai berikut:

a. Jika nilai $\mathrm{Z}>2,60$ maka perusahaan termasuk dalam kategori tidak bangkrut.

b. Jika nilai $1,10<\mathrm{Z}<2,60$ maka perusahaan termasuk dalam kategori grey area (tidak dapat ditentukan apakah perusahaan sehat ataupun mengalami kebangkrutan).

c. Jika nilai $\mathrm{Z}<1,10$ maka perusahaan termasuk dalam kategori bangkrut.

\section{METODE PENELITIAN}

Kriteria penarikan sampel yang digunakan oleh peneliti adalah sebagai berikut:

a. Perusahaan Batubara yang terdaftar di Bursa Efek Indonesia (BEI).

b. Perusahaan yang tidak delisting dan tidak listing selama periode penelitian.

c. Perusahaan Batubara yang mempublikasikan laporan keuangan dan data keuangan lainnya yang dibutuhkan oleh penulis selama waktu penelitian (periode 2011-2014).

Berdasarkan pada karakteristik pengambilan sampel maka jumlah sampel yang digunakan dalam penelitian ini adalah 18 perusahaan batubara.

Penelitian ini adalah penelitian deskriptif dengan menggunakan variabel Kelima Rasio Keuangan pada Metode Altman Z-Score.

Working Capital/Total Asset $\left(\mathrm{X}_{1}\right)$

Rasio ini merupakan rasio

yang menunjukkan kemampuan perusahaan untuk menghasilkan modal kerja bersih dari keseluruhan total aktiva yang dimilikinya. Rasio ini menggambarkan tingkat likuiditas dari suatu perusahaan. Working Capital adalah selisih dari aset lancar dan hutang lancar.

WCTA $=\frac{\text { Aktivalancar }- \text { Kewajiban }}{\text { TotalAset }}$

\section{Retained Earning/Total Asset $\left(\mathrm{X}_{2}\right)$}

Rasio ini merupakan rasio yang menunjukkan kemampuan perusahaan untuk menghasilkan laba ditahan dari total aktiva perusahaan. Rasio ini juga mengukur leverage perusahaan karena dari nilai rasio dapat pula diketahui proporsi aset dari perusahaan yang dibiayai dengan menggunakan laba yang dihasilkannya sendiri tanpa menggunakan hutang.

RETA $=\frac{\text { LabaDitahan }}{\text { TotalAset }}$

\section{EBIT/Total Asset $\left(\mathrm{X}_{3}\right)$}

Rasio ini merupakan rasio keuangan yang mengukur produktivitas perusahaan. Rasio ini menunjukkan kemampuan perusahaan untuk menghasilkan laba dari aktiva perusahaan, sebelum pembayaran bunga dan pajak.

EBITTA $=\frac{E B I T}{\text { Total Aset }}$

\section{Market Value of Equity/Book Value of Total Debt $\left(\mathrm{X}_{4}\right)$}

Rasio ini merupakan rasio yang menunjukkan kemampuan perusahaan untuk memenuhi kewajiban-kewajiban dari nilai pasar modal sendiri (saham biasa). Nilai buku modal diperoleh dengan mengalikan jumlah lembar saham biasa yang beredar dengan hargapasar per lembar saham biasa. Nilai buku hutang diperoleh dengan 
menunjukkan kewajiban lancar dengan kewajiban jangka panjang.

$B V E B V D=$

Jwhin soham baredar $x$ harge sahom Total Hutong

\section{Sales/Total Asset $\left(\mathrm{X}_{5}\right)$}

Rasio ini disebut juga dengan asset turnover dan biasanya dipergunakan untuk mengukur tingkat efisiensi manajemen dalam menggunakan keseluruhan aktiva perusahaan untuk menghasilkan penjualan dan mendapatkan laba. Semakin besar nilai dari rasio ini menggambarkan efektifitas manajemen dalam pengelolaan aset yang berarti menurunkan probabilitas default perusahaan.

\section{STA $=\frac{\text { Sales }}{\text { Total Asset }}$}

HASIL DAN

PEMBAHASAN

PENELITIAN

Hasil Penelitian
Analisis Laporan Keuangan

Berdasarkan Metode Prediksi Financial Distress Altman Z-Score

Perhitungan dengan menggunakan metode prediksi financial distress Altman Z-Score pada Perusahaan Batubara yang terdaftar di BEI selama periode tahun 2011 sampai 2014. Dimana rumusnya adalah sebagai berikut:

$Z=1,2 X 1+1,4 X 2+3,3 X 3+0,6 X 4+0,999 X 5$

Berdasarkan metode perhitungan Altman Z-Score dimana pada prediksi perhitungan tersebut perusahaan yang mempunyai skor $\mathrm{Z}>$ 2,99 diklasifikasikan sebagai perusahaan sehat, sedangkan perusahaan yang mempunyai skor $\mathrm{Z}<$ 1,81 diklasifikasikan sebagai perusahaan financial distress. Selanjutnya skor antara 1,81 sampai 2,99 diklasifikasikan sebagai perusahaan pada grey area atau daerah kelabu.

Tabel 3. Perhitungan Dengan Metode Financial Distress Z-Score Altman

Tahun 2011

\begin{tabular}{|c|c|c|c|c|c|c|c|c|}
\hline $\begin{array}{c}\text { Kode } \\
\text { Emiten }\end{array}$ & $\begin{array}{c}1,2 \\
\text { WCT } \\
\text { A } \\
\end{array}$ & $\begin{array}{c}1,4 \\
\text { RET } \\
\text { A }\end{array}$ & $\begin{array}{c}3,3 \\
\text { EBITT } \\
\mathbf{A} \\
\end{array}$ & $\begin{array}{c}\mathbf{0 , 6} \\
\text { MVEBV } \\
\text { D } \\
\end{array}$ & $\begin{array}{c}0,99 \\
\text { ST } \\
\text { A }\end{array}$ & $\begin{array}{c}\text { Z- } \\
\text { Score }\end{array}$ & Titik Cut-off & $\begin{array}{l}\text { Kategori Z- } \\
\text { Score }\end{array}$ \\
\hline ADRO & 0,11 & 0,23 & 0,75 & 1,16 & 0,7 & 2,95 & $\begin{array}{c}1,81<Z> \\
2,99\end{array}$ & Grey Area \\
\hline ARII & 0,13 & 0,03 & 0,35 & 2,99 & 0,35 & 3,84 & $Z>2,99$ & Sehat \\
\hline ATPK & 0,34 & $-2,35$ & 0,37 & 1,13 & 1,2 & 0,7 & $Z<1,81$ & Financial Distress \\
\hline BRAU & 0,15 & 0,12 & 1,05 & 0,62 & 0,8 & 2,74 & $\begin{array}{c}1,81<\mathrm{Z}> \\
2,99 \\
\end{array}$ & Grey Area \\
\hline BUMI & 0,04 & 0,09 & 0,71 & 0,48 & 0,54 & 1,86 & $\begin{array}{c}1,81<\mathrm{Z}> \\
2,99\end{array}$ & Grey Area \\
\hline BYAN & $-0,16$ & 0,26 & 0,91 & 4,53 & 0,94 & 6,47 & $Z>2,99$ & Sehat \\
\hline DEWA & 0,34 & $-0,02$ & $-0,06$ & 1,22 & 0,69 & 2,17 & $\begin{array}{c}1,81<\mathrm{Z}> \\
2,99\end{array}$ & Grey Area \\
\hline DOID & 0,26 & $-0,06$ & 0,23 & 0,33 & 0,64 & 1,41 & $Z<1,81$ & Financial Distress \\
\hline GEMS & 0,73 & 0,06 & 0,83 & 20,04 & 0,85 & 22,51 & $Z>2,99$ & Sehat \\
\hline GTBO & 0,46 & $-0,07$ & 1,09 & 6,36 & 0,7 & 8,55 & $Z>2,99$ & Sehat \\
\hline HRUM & 0,47 & 0,53 & 2,21 & 10,2 & 1,62 & 15,02 & $Z>2,99$ & Sehat \\
\hline ITMG & 0,47 & 0,61 & 1,86 & 5,81 & 1,49 & 10,24 & $Z>2,99$ & Sehat \\
\hline KKGI & 0,6 & 0,99 & 3,05 & 12,07 & 2,23 & 18,93 & $Z>2,99$ & Sehat \\
\hline MYOH & $-0,05$ & $-0,24$ & 0,62 & 5,03 & 2,05 & 7,42 & $Z>2,99$ & Sehat \\
\hline PKPK & 0,12 & 0,22 & 0,4 & 0,36 & 0,82 & 1,92 & $1,81<\mathrm{Z}<1,81$ & Grey Area \\
\hline PTBA & 0,72 & 0,84 & 1,51 & 7,18 & 0,91 & 11,17 & $Z>2,99$ & Sehat \\
\hline PTRO & $-0,02$ & 0,47 & 0,67 & 2,1 & 0,69 & 3,9 & $Z>2,99$ & Sehat \\
\hline SMMT & $-2,33$ & $-4,5$ & 4,18 & 3,95 & 3,19 & 4,48 & $Z>2,99$ & Sehat \\
\hline Tertinggi & 0,73 & 0,99 & 4,18 & 20,04 & 2,23 & 22,51 & & \\
\hline Terendah & $-2,33$ & $-4,5$ & $-0,06$ & $\mathbf{0 , 3 3}$ & 0,35 & $\mathbf{0 , 7}$ & & \\
\hline
\end{tabular}

Sumber: Data Diolah 
JURNAL PLANS

Penelitian Ilmu Manajemen \& Bisnis

ISSN: $1978-7057$

E-ISSN: 2527-306X

Pada tabel 3. dapat dilihat bahwa pada tahun 2011, perusahaan yang terkategori sehat ada 11 perusahaan atau sebesar $61,11 \%$. Perusahaan yang terkategori grey area ada 5 perusahaan atau sebesar $27,78 \%$, dan perusahaan dalam kategori financial distress ada 2 perusahaan atau $11,11 \%$.

Tabel 4. Perhitungan Dengan Metode Financial Distress Z-Score Altman Tahun 2012

\begin{tabular}{|c|c|c|c|c|c|c|c|c|}
\hline Kode Emiten & $\begin{array}{c}1,2 \\
\text { WCTA }\end{array}$ & $\begin{array}{c}1,4 \\
\text { RETA }\end{array}$ & $\begin{array}{c}\mathbf{3 , 3} \\
\text { EBITTA } \\
\end{array}$ & $\begin{array}{c}0,6 \\
\text { MVEBVD }\end{array}$ & $\begin{array}{l}0,99 \\
\text { STA }\end{array}$ & Z-Score & Titik Cut-off & Kategori Z-Score \\
\hline ADRO & 0,09 & 0,22 & 0,41 & 0,85 & 0,55 & 2,13 & $1,81<Z>2,99$ & Grey Area \\
\hline ARII & $-0,37$ & $-0,03$ & 0,18 & 1,82 & 0,32 & 1,93 & $1,81<Z>2,99$ & Grey Area \\
\hline ATPK & 0,33 & $-1,85$ & 0,28 & 0,66 & 1,19 & 0,61 & $\mathrm{Z}<1,81$ & Financial Distress \\
\hline BRAU & 0,1 & 0 & 0,78 & 0,22 & 0,71 & 1,82 & $1,81<Z>2,99$ & Grey Area \\
\hline BUMI & $-0,07$ & $-0,07$ & 0,35 & 0,11 & 0,52 & 0,84 & $Z<1,81$ & Financial Distress \\
\hline BYAN & 0,04 & 0,21 & 0,45 & 1,45 & 0,74 & 2,88 & $1,81<Z>2,99$ & Grey Area \\
\hline DEWA & 0,14 & $-0,15$ & $-0,15$ & 0,41 & 0,64 & 0,89 & $\mathrm{Z}<1,81$ & Financial Distress \\
\hline DOID & 0,19 & $-0,03$ & 0,16 & 0,07 & 0,72 & 1,11 & $\mathrm{Z}<1,81$ & Financial Distress \\
\hline GEMS & 0,45 & 0,09 & 0,69 & 15,56 & 1,14 & 17,92 & $Z>2,99$ & Sehat \\
\hline GTBO & 0,36 & 0,05 & 0,98 & 6,61 & 0,5 & 8,49 & $Z>2,99$ & Sehat \\
\hline HRUM & 0,51 & 0,55 & 1,95 & 9,15 & 1,92 & 14,08 & $Z>2,99$ & Sehat \\
\hline ITMG & 0,43 & 0,57 & 1,64 & 0,6 & 1,62 & 4,86 & $Z>2,99$ & Sehat \\
\hline KKGI & 0,27 & 1,06 & 2,2 & 5,03 & 2,05 & 10,62 & $Z>2,99$ & Sehat \\
\hline $\mathrm{MYOH}$ & $-0,05$ & $-0,04$ & 0,59 & 0,73 & 1,37 & 2,61 & $1,81<Z>2,99$ & Grey Area \\
\hline PKPK & 0,19 & 0,21 & 0,36 & 0,37 & 0,74 & 1,86 & $1,81<Z>2,99$ & Grey Area \\
\hline PTBA & 0,65 & 0,82 & 1,32 & 4,94 & 0,9 & 8,63 & $Z>2,99$ & Sehat \\
\hline PTRO & 0,09 & 0,41 & 0,7 & 0,24 & 0,72 & 2,16 & $1,81<\mathrm{Z}>2,99$ & Grey Area \\
\hline SMMT & 0,33 & 0 & 0,11 & 57,29 & 0,03 & 57,77 & $Z>2,99$ & Sehat \\
\hline Tertinggi & 0,65 & 1,06 & 2,2 & 57,29 & 2,05 & 57,77 & & \\
\hline Terendah & $-0,37$ & $-1,85$ & $-0,15$ & 0,07 & 0,03 & 0,61 & & \\
\hline
\end{tabular}

Sumber: Data Diolah

Pada tabel 4. dapat dilihat bahwa pada tahun 2012, perusahaan yang terkategori sehat ada 7 perusahaan atau sebesar $38,89 \%$. Perusahaan yang terkategori grey area ada 7 perusahaan atau sebesar $38,89 \%$, dan perusahaan dalam kategori financial distress ada 4 perusahaan atau sebesar $22,22 \%$. 
JURNAL PLANS

Penelitian Ilmu Manajemen \& Bisnis

ISSN: $1978-7057$

E-ISSN: 2527-306X

Tabel 5. Perhitungan Dengan Metode Financial Distress Z-Score Altman

Tahun 2013

\begin{tabular}{|c|c|c|c|c|c|c|c|c|}
\hline Kode Emiten & $\begin{array}{c}1,2 \\
\text { WCTA } \\
\end{array}$ & $\begin{array}{c}1,4 \\
\text { RETA } \\
\end{array}$ & $\begin{array}{c}3,3 \\
\text { EBITTA } \\
\end{array}$ & $\begin{array}{c}0,6 \\
\text { MVEBVD } \\
\end{array}$ & $\begin{array}{r}0,99 \\
\text { STA } \\
\end{array}$ & Z-Score & Titik Cut-off & Kategori Z-Score \\
\hline ADRO & 0,11 & 0,25 & 0,36 & 0,48 & 0,48 & 1,69 & $Z<1,81$ & Financial Distress \\
\hline ARII & $-0,48$ & $-0,07$ & $-0,03$ & 0,69 & 0,36 & 0,47 & $\mathrm{Z}<1,81$ & Financial Distress \\
\hline ATPK & 0,07 & $-0,17$ & 0,08 & 2,53 & 0,27 & 2,78 & $1,81<Z>2,99$ & Grey Area \\
\hline BRAU & 0,03 & 0 & 0,56 & 0,17 & 0,7 & 1,46 & $Z<1,81$ & Financial Distress \\
\hline BUMI & $-0,48$ & $-0,21$ & 0,32 & 0,04 & 0,5 & 0,18 & $\mathrm{Z}<1,81$ & Financial Distress \\
\hline BYAN & 0,03 & 0,04 & 0,34 & 1,25 & 0,73 & 2,39 & $1,81<Z>2,99$ & Grey Area \\
\hline DEWA & 0,1 & $-0,38$ & $-0,1$ & 0,37 & 0,6 & 0,6 & $\mathrm{Z}<1,81$ & Financial Distress \\
\hline DOID & 0,14 & $-0,12$ & 0,34 & 0,04 & 0,64 & 1,03 & $\mathrm{Z}<1,81$ & Financial Distress \\
\hline GEMS & 0,25 & 0,07 & 0,64 & 7,29 & 1,09 & 9,34 & $Z>2,99$ & Sehat \\
\hline GTBO & 0,66 & 0,78 & 0,06 & 12,49 & 0,32 & 14,3 & $Z>2,99$ & Sehat \\
\hline HRUM & 0,5 & 0,53 & 1,21 & 4,27 & 1,72 & 8,24 & $Z>2,99$ & Sehat \\
\hline ITMG & 0,32 & 0,57 & 1,21 & 3,7 & 1,55 & 7,35 & $Z>2,99$ & Sehat \\
\hline KKGI & 0,23 & 1,18 & 1,67 & 3,69 & 1,81 & 8,57 & $Z>2,99$ & Sehat \\
\hline MYOH & 0,25 & 0,11 & 0,63 & 0,63 & 1,34 & 2,96 & $1,81<Z>2,99$ & Grey Area \\
\hline PKPK & 0,27 & 0,24 & 0,34 & 0,17 & 0,55 & 1,57 & $Z<1,81$ & Financial Distress \\
\hline PTBA & 0,43 & 0,97 & 0,98 & 3,42 & 0,95 & 6,75 & $Z>2,99$ & Sehat \\
\hline PTRO & 0,16 & 0,45 & 0,59 & 0,18 & 0,7 & 2,08 & $1,81<\mathrm{Z}>2,99$ & Grey Area \\
\hline SMMT & 0,28 & 0,04 & 0,11 & 19,62 & 0 & 20,04 & $Z>2,99$ & Sehat \\
\hline Tertinggi & 0,66 & 1,18 & 1,67 & 19,62 & 1,81 & 20,04 & & \\
\hline Terendah & $-0,48$ & $-0,38$ & $-0,1$ & 0,04 & 0 & 0,18 & & \\
\hline
\end{tabular}

Sumber: Data Diolah

Pada tabel 5. dapat dilihat bahwa pada tahun 2013, perusahaan yang terkategori sehat ada 7 perusahaan atau sebesar $38,89 \%$. Perusahaan yang terkategori grey

area ada 4 perusahaan atau sebesar $22,22 \%$, dan perusahaan dalam kategori financial distress ada 7 perusahaan atau sebesar $38,89 \%$.

Tabel 6. Perhitungan Dengan Metode Financial Distress Z-Score Altman Tahun 2014

\begin{tabular}{|c|c|c|c|c|c|c|c|c|}
\hline Kode Emiten & $\begin{array}{c}1,2 \\
\text { WCTA }\end{array}$ & $\begin{array}{c}1,4 \\
\text { RETA }\end{array}$ & $\begin{array}{c}3,3 \\
\text { EBITTA } \\
\end{array}$ & $\begin{array}{c}0,6 \\
\text { MVEBVD }\end{array}$ & $\begin{array}{l}0,99 \\
\text { STA } \\
\end{array}$ & Z-Score & Titik Cut-off & Kategori Z-Score \\
\hline ADRO & 0,09 & 0,29 & 0,37 & 0,51 & 0,51 & 1,77 & $\mathrm{Z}<1,81$ & Financial Distress \\
\hline ARII & $-0,35$ & $-0,16$ & $-0,09$ & 0,28 & 0,11 & $-0,21$ & $\mathrm{Z}<1,81$ & Financial Distress \\
\hline ATPK & 0,32 & $-0,1$ & 0,29 & 1,16 & 0,37 & 2,05 & $1,81<Z>2,99$ & Grey Area \\
\hline BRAU & $-0,29$ & 0 & 0,51 & 0,06 & 0,76 & 1,05 & $\mathrm{Z}<1,81$ & Financial Distress \\
\hline BUMI & $-0,82$ & $-0,31$ & 0,25 & 0,02 & 0,42 & $-0,44$ & $Z<1,81$ & Financial Distress \\
\hline BYAN & $-0,2$ & $-0,11$ & 0,28 & 1,18 & 0,71 & 1,85 & $1,81<Z>2,99$ & Grey Area \\
\hline
\end{tabular}


JURNAL PLANS

Penelitian Ilmu Manajemen \& Bisnis

ISSN: $1978-7057$

E-ISSN: 2527-306X

\begin{tabular}{|l|r|r|r|r|r|r|r|c|}
\hline DEWA & 0,16 & $-0,39$ & 0,13 & 0,39 & 0,65 & 0,94 & $\mathrm{Z}<1,81$ & Financial Distress \\
\hline DOID & 0,23 & $-0,12$ & 0,45 & 0,09 & 0,66 & 1,32 & $\mathrm{Z}<1,81$ & Financial Distress \\
\hline GEMS & 0,29 & 0,11 & 1,47 & 8,39 & 1,31 & 11,58 & $\mathrm{Z}>2,99$ & Sehat \\
\hline GTBO & 0,09 & 0,74 & $-0,13$ & 3,52 & 0,36 & 4,58 & $\mathrm{Z}>2,99$ & Sehat \\
\hline HRUM & 0,55 & 0,49 & 0,65 & 2,64 & 1,06 & 5,38 & $\mathrm{Z}>2,99$ & Sehat \\
\hline ITMG & 0,19 & 0,54 & 1,03 & 2,05 & 1,47 & 5,28 & $\mathrm{Z}>2,99$ & Sehat \\
\hline KKGI & 0,19 & 1,25 & 0,74 & 1,77 & 1,35 & 5,31 & $\mathrm{Z}>2,99$ & Sehat \\
\hline MYOH & 0,28 & 0,24 & 0,73 & 0,59 & 1,47 & 3,31 & $\mathrm{Z}>2,99$ & Sehat \\
\hline PKPK & 0,12 & 0,15 & $-0,06$ & 0,2 & 0,25 & 0,67 & $\mathrm{Z}<1,81$ & Financial Distress \\
\hline PTBA & 0,31 & 0,87 & 0,9 & 2,81 & 0,87 & 5,77 & $\mathrm{Z}>2,99$ & Sehat \\
\hline PTRO & 0,18 & 0,48 & 0,47 & 0,16 & 0,74 & 2,03 & $1,81<\mathrm{Z}>2,99$ & Grey Area \\
\hline SMMT & 0,05 & 0,03 & 0,03 & 12,65 & 0,01 & 12,76 & $\mathrm{Z}>2,99$ & Sehat \\
\hline Tertinggi & 0,55 & 1,25 & 1,47 & 12,65 & 1,47 & 12,76 & & \\
\hline Terendah & $-0,82$ & $-0,39$ & $-0,13$ & 0,02 & 0,01 & $-0,44$ & & \\
\hline
\end{tabular}

Sumber: Data Diolah

Pada tabel 6. dapat dilihat bahwa pada tahun 2014, perusahaan yang terkategori sehat ada 8 perusahaan atau sebesar $44,44 \%$. Perusahaan yang terkategori grey area ada 3 perusahaan atau sebesar $16,67 \%$, dan perusahaan dalam kategori financial distress ada 7 perusahaan atau sebesar 38,89\%.

Tabel 7.

Perhitungan Dengan Metode Financial Distress Z-Score Altman Tahun 2015

\begin{tabular}{|l|r|r|r|r|r|r|r|c|}
\hline Kode Emiten & $\begin{array}{c}\mathbf{1 , 2} \\
\text { WCTA }\end{array}$ & $\begin{array}{c}\mathbf{1 , 4} \\
\text { RETA }\end{array}$ & $\begin{array}{c}\mathbf{3 , 3} \text { EBITTA } \\
\text { MVEBVD }\end{array}$ & $\begin{array}{c}\mathbf{0 , 9 9} \\
\text { STA }\end{array}$ & Z-Score & Titik Cut-off & Kategori Z-Score \\
\hline ADRO & 0,13 & 0,33 & 0,08 & 0,28 & 0,45 & 1,26 & $\mathrm{Z}<1,81$ & Financial Distress \\
\hline ARII & $-0,52$ & $-0,28$ & $-0,24$ & 0,19 & 0,08 & $-0,76$ & $\mathrm{Z}<1,81$ & Financial Distress \\
\hline ATPK & 0,28 & $-0,23$ & $-0,30$ & 0,88 & 0,14 & 0,76 & $\mathrm{Z}<1,81$ & Financial Distress \\
\hline BRAU & --- & --- & --- & --- & --- & --- & --- & --- \\
\hline BUMI & --- & --- & --- & --- & --- & --- & --- & --- \\
\hline BYAN & 0,17 & $-0,23$ & $-0,29$ & 1,49 & 0,49 & 1,63 & $\mathrm{Z}<1,81$ & Financial Distress \\
\hline DEWA & 0,09 & $-0,36$ & 0,00 & 0,32 & 0,64 & 0,69 & $\mathrm{Z}<1,81$ & Financial Distress \\
\hline DOID & 0,30 & $-0,15$ & $-0,03$ & 0,03 & 0,67 & 0,81 & $\mathrm{Z}<1,81$ & Financial Distress \\
\hline GEMS & 0,41 & $-0,10$ & 0,02 & 2,93 & 0,95 & 4,21 & $\mathrm{Z}>2,99$ & Sehat \\
\hline GTBO & --- & --- & --- & --- & --- & --- & --- & -- \\
\hline HRUM & 0,61 & 0,50 & $-0,17$ & 2,13 & 0,65 & 3,72 & $\mathrm{Z}>2,99$ & Sehat \\
\hline ITMG & 0,23 & 0,53 & 0,18 & 0,82 & 1,34 & 3,09 & $\mathrm{Z}>2,99$ & Sehat \\
\hline KKGI & 0,26 & 1,35 & 0,19 & 0,84 & 1,12 & 3,75 & $\mathrm{Z}>2,99$ & Sehat \\
\hline MYOH & 0,36 & 0,51 & 0,51 & 0,74 & 1,39 & 3,51 & $\mathrm{Z}>2,99$ & Sehat \\
\hline
\end{tabular}


JURNAL PLANS

Penelitian Ilmu Manajemen \& Bisnis

ISSN: $1978-7057$

E-ISSN: 2527-306X

\begin{tabular}{|l|r|r|r|r|r|r|r|c|}
\hline PKPK & $-0,12$ & 0,23 & $-1,19$ & 0,21 & 0,12 & $-0,76$ & $\mathrm{Z}<1,81$ & Financial Distress \\
\hline PTBA & 0,19 & 0,85 & 0,40 & 0,82 & 0,81 & 3,06 & $\mathrm{Z}>2,99$ & Sehat \\
\hline PTRO & 0,14 & 0,48 & $-0,10$ & 0,05 & 0,48 & 1,05 & $\mathrm{Z}<1,81$ & Financial Distress \\
\hline SMMT & $-0,07$ & $-0,07$ & $-0,10$ & 1,03 & 0,04 & 0,65 & $\mathrm{Z}<1,81$ & Sehat \\
\hline Tertinggi & 0,61 & 1,35 & $-0,10$ & 2,93 & 1,39 & 4,21 & & \\
\hline Terendah & $-0,52$ & $-0,36$ & $-0,10$ & 0,03 & 0,04 & $-0,76$ & & \\
\hline
\end{tabular}

Sumber: Data Diolah

Pada tabel 7. dapat dilihat bahwa pada tahun 2015, perusahaan yang terkategori sehat ada 7 perusahaan atau sebesar 46,67\%. Dan perusahaan dalam kategori financial distress ada 8 perusahaan atau sebesar 53,33\%.

\section{Pembahasan Penelitian}

Klasifikasi masing-masing perusahaan batubara mulai dari tahun 2011 sampai 2015 berdasarkan perhitungan metode Altman Z-Score dapat dilihat pada tabel 8. dan 9. Dari tabel dibawah ini dapat dilihat perkembangan perusahaan setiap tahunnya.

Tabel 8. Perhitungan Z-Score dari Tahun 2011 sampai 2015

\begin{tabular}{|l|r|r|r|r|r|}
\hline \multirow{2}{*}{ Kode Emiten } & \multicolumn{5}{|c|}{ Tahun } \\
\cline { 2 - 6 } & $\mathbf{2 0 1 1}$ & $\mathbf{2 0 1 2}$ & $\mathbf{2 0 1 3}$ & $\mathbf{2 0 1 4}$ & $\mathbf{2 0 1 5}$ \\
\hline ADRO & 2,95 & 2,13 & 1,69 & 1,77 & 1,26 \\
\hline ARII & 3,84 & 1,93 & 0,47 & $-0,21$ & $-0,76$ \\
\hline ATPK & 0,7 & 0,61 & 2,78 & 2,05 & 0,76 \\
\hline BRAU & 2,74 & 1,82 & 1,46 & 1,05 & --- \\
\hline BUMI & 1,86 & 0,84 & 0,18 & $-0,44$ & --- \\
\hline BYAN & 6,47 & 2,88 & 2,39 & 1,85 & 1,63 \\
\hline DEWA & 2,17 & 0,89 & 0,6 & 0,94 & 0,69 \\
\hline DOID & 1,41 & 1,11 & 1,03 & 1,32 & 0,81 \\
\hline GEMS & 22,51 & 17,92 & 9,34 & 11,58 & 4,21 \\
\hline GTBO & 8,55 & 8,49 & 14,3 & 4,58 & --- \\
\hline HRUM & 15,02 & 14,08 & 8,24 & 5,38 & 3,72 \\
\hline ITMG & 10,24 & 4,86 & 7,35 & 5,28 & 3,09 \\
\hline KKGI & 18,93 & 10,62 & 8,57 & 5,31 & 3,75 \\
\hline MYOH & 7,42 & 2,61 & 2,96 & 3,31 & 3,51 \\
\hline PKPK & 1,92 & 1,86 & 1,57 & 0,67 & $-0,76$ \\
\hline PTBA & 11,17 & 8,63 & 6,75 & 5,77 & 3,06 \\
\hline PTRO & 3,9 & 2,16 & 2,08 & 2,03 & 1,05 \\
\hline SMMT & 4,48 & 57,77 & 20,04 & 12,76 & 0,65 \\
\hline Rata - Rata & 7,02 & 7,85 & 5,1 & 3,61 & 1,48 \\
\hline Sunyyyyyy
\end{tabular}

Sumber: Data Diolah

Tabel 9. Klasifikasi Perusahaan Berdasarkan Metode Altman Z-Score dari Tahun 2011 sampai 2015

\begin{tabular}{|c|c|c|c|c|c|}
\hline \multirow{2}{*}{$\begin{array}{l}\text { Kode } \\
\text { Emiten }\end{array}$} & \multicolumn{5}{|c|}{ Tahun } \\
\hline & 2011 & 2012 & 2013 & 2014 & 2015 \\
\hline ADRO & Grey Area & Grey Area & $\begin{array}{l}\text { Financial } \\
\text { Distress }\end{array}$ & $\begin{array}{l}\text { Financial } \\
\text { Distress }\end{array}$ & $\begin{array}{l}\text { Financial } \\
\text { Distress }\end{array}$ \\
\hline
\end{tabular}


JURNAL PLANS

Penelitian Ilmu Manajemen \& Bisnis

ISSN: $1978-7057$

E-ISSN: 2527-306X

\begin{tabular}{|c|c|c|c|c|c|}
\hline ARII & Sehat & Grey Area & $\begin{array}{l}\text { Financial } \\
\text { Distress }\end{array}$ & $\begin{array}{l}\text { Financial } \\
\text { Distress }\end{array}$ & $\begin{array}{l}\text { Financial } \\
\text { Distress }\end{array}$ \\
\hline ATPK & $\begin{array}{l}\text { Financial } \\
\text { Distress }\end{array}$ & $\begin{array}{l}\text { Financial } \\
\text { Distress } \\
\end{array}$ & Grey Area & Grey Area & $\begin{array}{l}\text { Financial } \\
\text { Distress } \\
\end{array}$ \\
\hline BRAU & Grey Area & Grey Area & $\begin{array}{l}\text { Financial } \\
\text { Distress }\end{array}$ & $\begin{array}{l}\text { Financial } \\
\text { Distress }\end{array}$ & --- \\
\hline BUMI & Grey Area & $\begin{array}{l}\text { Financial } \\
\text { Distress }\end{array}$ & $\begin{array}{l}\text { Financial } \\
\text { Distress }\end{array}$ & $\begin{array}{l}\text { Financial } \\
\text { Distress }\end{array}$ & --- \\
\hline BYAN & Sehat & Sehat & Grey Area & Grey Area & $\begin{array}{l}\text { Financial } \\
\text { Distress }\end{array}$ \\
\hline $\begin{array}{l}\text { DEW } \\
\text { A }\end{array}$ & Grey Area & $\begin{array}{l}\text { Financial } \\
\text { Distress }\end{array}$ & $\begin{array}{l}\text { Financial } \\
\text { Distress }\end{array}$ & $\begin{array}{l}\text { Financial } \\
\text { Distress }\end{array}$ & $\begin{array}{l}\text { Financial } \\
\text { Distress }\end{array}$ \\
\hline DOID & $\begin{array}{l}\text { Financial } \\
\text { Distress }\end{array}$ & $\begin{array}{l}\text { Financial } \\
\text { Distress }\end{array}$ & $\begin{array}{l}\text { Financial } \\
\text { Distress }\end{array}$ & $\begin{array}{l}\text { Financial } \\
\text { Distress }\end{array}$ & $\begin{array}{l}\text { Financial } \\
\text { Distress }\end{array}$ \\
\hline GEMS & Grey Area & Sehat & Sehat & Sehat & Sehat \\
\hline GTBO & Grey Area & Sehat & Sehat & Sehat & --- \\
\hline $\begin{array}{l}\text { HRU } \\
M\end{array}$ & Grey Area & Sehat & Sehat & Sehat & Sehat \\
\hline ITMG & Grey Area & Sehat & Sehat & Sehat & Sehat \\
\hline KKGI & Grey Area & Sehat & Sehat & Sehat & Sehat \\
\hline $\begin{array}{l}\text { MYO } \\
\mathrm{H}\end{array}$ & Grey Area & Grey Area & Grey Area & Sehat & Sehat \\
\hline PKPK & $\begin{array}{l}\text { Financial } \\
\text { Distress }\end{array}$ & Grey Area & $\begin{array}{l}\text { Financial } \\
\text { Distress }\end{array}$ & $\begin{array}{l}\text { Financial } \\
\text { Distress }\end{array}$ & $\begin{array}{l}\text { Financial } \\
\text { Distress }\end{array}$ \\
\hline PTBA & Grey Area & Sehat & Sehat & Sehat & Sehat \\
\hline PTRO & Grey Area & Grey Area & Grey Area & Grey Area & $\begin{array}{l}\text { Financial } \\
\text { Distress }\end{array}$ \\
\hline SMMT & Grey Area & Sehat & Sehat & Sehat & Sehat \\
\hline
\end{tabular}

Sumber: Data Diolah

Pada tabel 8. dan tabel 9. dapat dilihat perkembangan nilai ZScore ataupun klasifikasi dari setiap perusahaan mulai tahun 2011 sampai 2015. Dimana 8 perusahaan dari 18 perusahaan sampel penelitian tersebut diklasifikasikan sehat, yaitu PT Golden Energy Mines Tbk (GEMS), PT Garda Tujuh Buana Tbk (GTBO), PT Harum Energy Tbk (HRUM), PT Indo Tambangraya Megah Tbk (ITMG), PT Resource Alam Indonesia Tbk (KKGI), PT Samindo Resources Tbk (MYOH), PT Tambang Batubara Bukit Asam (Persero) Tbk (PTBA), dan PT Golden Eagle Energy Tbk (SMMT).

Dan 10 perusahaan dari 18 perusahaan sampel diklasifikasikan berpotensi financial distress, yaitu PT. Adaro Enery Tbk (ADRO), Atlas
Resources Tbk (ARII), PT Bara Jaya International Tbk (ATPK), PT Berau Coal Energy Tbk (BRAU), PT Bumi Resources Tbk (BUMI), PT Bayan Resources Tbk (BYAN), PT Bumi Resources Tbk(BUMI), PT Darma Henwa Tbk (DEWA) dan PT Delta Dunia Makmur Tbk (DOID), PT Perdana Karya Perkasa Tbk (PKPK) dan PT Petrosea Tbk (PTRO).

Pada perusahaan batubara yang menjadi sampel dalam penelitian ini lebih banyak yang mengalami kondisi financial distress atau sebesar $56.67 \%$ perusahaan. Perusahaan mengalami financial distress disebabkan oleh faktor internal dan faktor eksternal yang saling mempengaruhi satu sama lain. Rasio - rasio keuangan Altman pada penelitian ini 
digolongkan pada tiga kelompok besar, yaitu Rasio likuiditas yang terdiri dari $\mathrm{X}_{1}$, Rasio Profitabilitas yang terdiri dari $X_{2}$ dan $X_{3}$, dan Rasio Aktivitas yang terdiri $\mathrm{X}_{4}$ dan $\mathrm{X}_{5}$. Rasio aktivitas adalah rasio yang mengukur seberapa efektif perusahaan dalam memanfaatkan semua sumber daya yang ada padanya dalam menghasilkan keuntungan. Rasio aktivitas pada penelitian ini setiap tahunnya mengalami penurunan baik untuk perusahaan sehat maupun yang mengalami financial distress. Sebagian besarnya rasio aktivitas menurun karena nilai dari penjualan dan harga saham yang dimiliki oleh perusahaan mengalami penurunan dan hutang dari perusahaan semakin meningkat una untuk memenuhi besarnya biaya tetap yang harus dikeluarkan oleh perusahaan.

$$
\text { Penyebab penjualan }
$$

perusahaan menurun karena terjadinya perlambatan ekonomi China yang dimana China merupakan negara dengan ekonomi terbesar kedua di dunia ini adalah mitra dagang yang palimg penting bagi Indonesia. Karena perlambatan tersebut, China mengeluarkan kebijakan baru yaitu membatasi impor batubara berkalori rendah. Perihal pembatasan tersebut, perusahaan batubara di Indonesia juga terkendala dalam melakukan ekspor batubara.

Dimana sebelum adanya pembatasan tersebut penjualan ekspor yang dilakukan perusahaan batubara Indonesia mulai dari tahun 2009 hingga tahun 2013 terus mengalami kenaikan hingga mencapai angka 402 juta ton dan dari tahun 2014 dan 2015 mengalami penurunan yang mencapai angka 296 juta ton. Karena terjadinya penurunan terhadap penjualan perusahaan, maka akan berdampak pada rasio profitabilitas perusahaan. Rasio profitabilitas merupakan rasio yang bertujuan untuk mengetahui kemampuan perusahaan dalam menghasilkan laba selama periode tertentu dan juga memberikan gambaran tentang tingkat efektifitas manajemen dalam melaksanakan kegiatan operasinya. Efektifitas manajemen dapat dilihat dari laba yang dihasilkan terhadap penjualan dan investasi perusahaan.Kegiatan dari penjualan ekspor terkendala, sedangkan produksi batubara dari tahun ke tahun terus mengalami peningkatan. Akibatnya terjadi kelebihan kapasitas atau penawaran di pasar China sehingga menyebabkan harga jual dari batubara menurun mulai dari tahun 2014. Karena harga jual batubara menurun secara terusmenerus dari tahun 2014 berdampak pada menurunnya pendapatan yang diterima oleh perusahaan batubara. Dengan pendapatan yang menurun dan besarnya biaya produksi yang dikeluarkan oleh pihak perusahaan berakibat pada pendapatan bersih yang diterima perusahaan. 


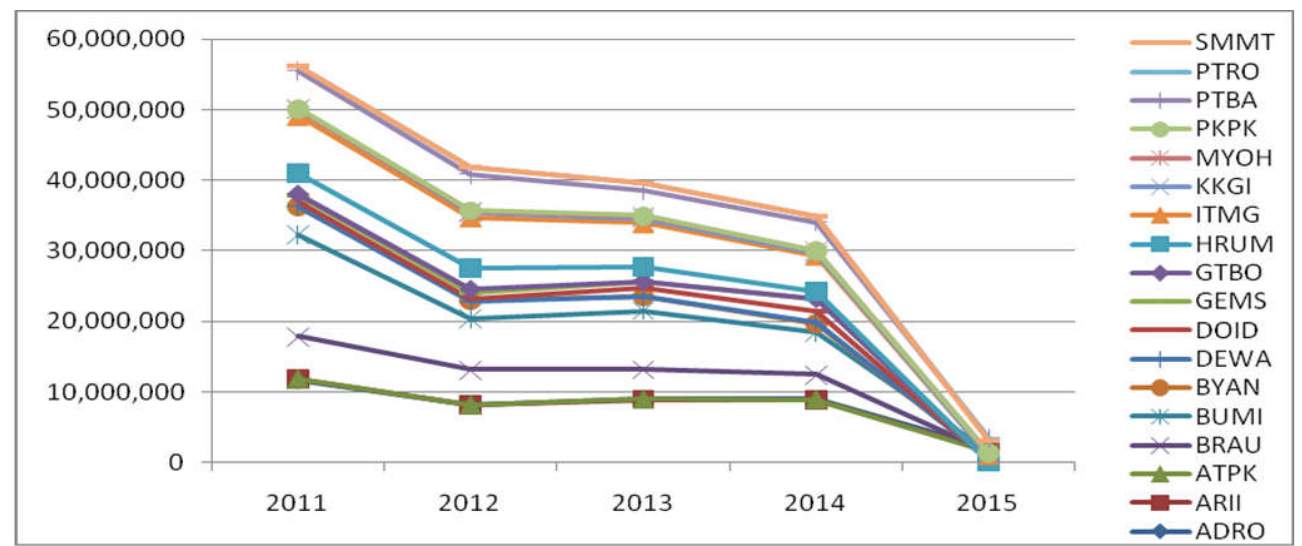

Gambar 2. Perkembangan EBIT Perusahaan Batubara 2011 - 2015

Dari gambar 2. dapat dilihat bahwa pendapatan yang diterima perusahaan batubara secara umum mengalami penurunan bahkan sampai mengalami kerugian selama 3 tahun. Seperti perusahaan ARII, yang mengalami penurunan pendapatan bahkan mengalami kerugian hingga tahun 2015 yaitu di tahun 2011 memperoleh pendapatan sebesar Rp 246.060.000.000,- sampai pada tahun 2015 rugi sebesar $\mathrm{Rp}$ 357.594.000.000,-. Perusahaan ini mengalami kerugian selama tiga tahun berturut - turut dari tahun 2013 sampai 2015.

Selain itu, perusahaan PKPK juga mengalami kerugian saat melakukan kegiatan operasionalnya dari tahun 2011 sampai 2015, yaitu di tahun 2011 perusahaan ini memperoleh pendapatan sebesar $\mathrm{Rp}$ 57.047.000.000,- sampai pada tahun 2015 rugi sebesar Rp 61.713.000.000,-. Dan bukan hanya pada 2015 saja perusahaan ini mengalami kerugian, tetapi dari tahun 2014 perusahaan ini sudah mengalami kerugian.

Karena terjadi
bahkan rugi pada
perusahaan bendapatan
berdampak juga pada

penurunan harga saham perusahaan. Selain karena hal itu, penurunan harga saham disebabkan juga karena jumlah hutang yang dimiliki perusahaan setiap tahunnya meningkat. Pada perusahaan batubara ini, jumlah hutang yang dominan meningkat tiap tahunnya adalah hutang jangka pendek yang artinya hutang tersebut digunakan perusahaan untuk membiayai kegiatan operasional perusahaannya. Dimana penambahan pada hutang jangka pendek tersebut dapat mempengaruhi modal kerja perusahaan. Perusahaan harus menjaga keseimbangan antara jumlah aktiva lancar dan jumlah hutang lancar agar dapat menjaga tingkat likuidasi perusahaan.

Dengan kondisi yang saat ini terjadi, perusahaan juga masih di pusingkan dengan kebijakan yang dikeluarkan oleh pemerintah Indonesia, yaitu kebijakan smelter yang diterbitkan permerintah Indonesia yang berisikan aturan yang melarang ekspor bahan mineral mentah. Dengan adanya kebijakan tersebut, perusahaan diwajibkan membangun smelter atau setidaknya melakukan kerjasama dengan perusahaan smelting. 


\begin{abstract}
Apabila perusahaan tidak melakukannya, pemerintah akan memberi sanksi diantaranya menghentikan kontrak karya bagi perusahaan tambang di Indonesia yang tidak memenuhi kewajiban membangun smelter hingga akhir 2014. Kewajiban membangun smelter tertuang dalam UU No. 4/2009 tentang Mineral dan Batubara atau Minerba, diantaranya mengatur ekspor bahan tambang yang belum dimurnikan dan larangan bagi perusahaan tambang di Indonesia untuk mengekspor bahan tambang mentah mulai Januari 2014.
\end{abstract}

$$
\text { Alasan pemerintah }
$$

menerbitkan kebijakan ini adalah untuk meningkatkan pertumbuhan ekonomi di Indonesia, dapat memberikan peluang tenaga kerja baru, serta pengolahan bahan mentah kebahan jadi tidak perlu diekspor dan akan dilakukan di dalam negeri sendiri yang pada akhirnya investor akan datang untuk membuka tempat pengolahan tersebut.

Maka dari itu, masalah ini membuat perusahaan batubara seperti peribahasa sudah jatuh ke timpa tangga. Masalah besarnya biaya dalam menjalankan kegiatan operasional belum terselesaikan, ditambah lagi dengan kewajiban dalam melakukan pembangunan smelter.

\section{PENUTUP}

Berdasarkan pada hasil penelitian bab sebelumnya, maka terdapat beberapa hal yang dapat disimpulkan sebagai berikut:

1. Hasil penelitian ini selama lima tahun pengamatan, rasio keuangan dalam Altman dapat menjelaskan kondisi financial distress pada perusahaan batubara yang terdaftar di Bursa Efek Indonesia. Pada perusahaan batubara yang menjadi sampel dalam penelitian ini lebih banyak yang mengalami kondisi financial distress atau sebesar $56.67 \%$ perusahaan.

2. Faktor - faktor penyebab terjadinya financial distress pada perusahaan ini adalah faktor internal yaitu besarnya jumlah hutang dan biaya yang dikeluarkan perusahaan, terjadinya penurunan terhadap penjualan, pendapatan yang diterima perusahaan. Sedangkan faktor eksternalnya yaitu, terjadinya perlambatan ekonomi China yan disertai dengan menurunnya harga batubara dan adanya kebijakan smelter yang dikeluarkan pemerintah Indonesia.

\section{DAFTAR PUSTAKA}

Altman, E.L. 1968. Financial Ratio, Discrminant Analysis, and The Prediction of Corporate Bankcrupcty. The Jurnal of Finance. September (2005).

Anggarini, Tifani

Vota.2010."Pengaruh

Karakteristik Komite Audit Terhadap Financial Distress (Studi Empiris Pada Perusahaan yang Terdaftar di Bursa Efek Indonesia"Skripsi S-1, Program Studi Akuntansi Universitas Diponegoro Semarang.

Charles T.Horngren dan Walter t. Harrison.2010.Akuntansi Jilid Satu.Edisi Tujuh.Jakarta: Penerbit Erlangga

Dwi, Prastowo.2011.Analisis Laporan Keuangan Konsep dan Aplikasi.Edisi Ketiga.Cetakan Pertama.Yogyakarta: UPP STIM YKPN

Emrinaldi.2007."Analisis Pengaruh Praktek Tata Kelola 
JURNAL PLANS

Penelitian Ilmu Manajemen \& Bisnis

ISSN: $1978-7057$

E-ISSN: 2527-306X

$\begin{array}{lr}\text { Perusahaan } & \text { (Corporate } \\ \text { Governance) } & \text { Terhadap } \\ \text { Kesulitan } & \text { Keuangan } \\ \text { Perusahaan } & \text { (Financial } \\ \text { Distress):Suatu } & \text { Kajian } \\ \text { Empiris.Jurnal } & \text { Bisnis dan } \\ \text { Akuntansi, Vol. 9, No. 1, : 88- } \\ 104\end{array}$

Fahmi, Irfan. 2011. Analisis Laporan Keuangan. Bandung : Alfabeta.

Fitriyah, Ida. 2013. Pengaruh Rasio Keuangan Terhadap Financial Distress Pada Perusahaan Properti

Gitman, I. J.2002.Principles of Managerial Finance Ed. 10. Harper and Row Publisher, New York.

Hamid, Abdul. 2007.Panduan Penulisan Skripsi.Cetakan 1. Jakarta : FEIS UINPres

http://www.batamtoday.com/berita45

373-Industri-Batubara-Cina-

Melemah,-Berpotensi-RugikanIndonesia.html

Ikatan Akuntan Indonesia. 2009. Standar Akuntansi Keuangan. Salemba Empat. Jakarta.

Kamaluddin dan Pribadi, Karina Ayu.2011.prediksi Financial Distress Kasus Industri Manufaktur Pendekatan Model Regresi Logistik.Jurnal Ilmiah STIE MDP.September Vol 1. No.1. hal. 11-23

Kasmir. 2010. Pengantar Manajemen Keuangan. Jakarta : Kencana.

Luciana.2006.Prediksi Kondisi Financial Distress Perusahaan Go Publik dengan Menggunakan Analisis Multinomial Logit.Jurnal Ekonomi dan Bisnis Vol. 12 No. 1

Luciana dan Emmanue.2003.Analisis Rasio Keuangan untuk
Memprediksi Kondisi Financial
Distress
Perusahaan
Manufaktur yang Terdaftar di Burs Efek Jakarta.Jurnal
Akuntansi dan Auditing Indonesia (JAAI). Vol 7 No.2

Mas'ud, Imam dan Reva.2012. Analisis Rasio Keuangan Untuk Memprediksi KondisiFinancial Distress Perusahaan Manufaktur yangTerdaftar Di Bursa Efek Indonesia.Jurnal Akuntansi Universitas Jember.

Mokhamad Iqbal Dwi Nugroho dan Wisnu Mawardi.2012.Analisis Prediksi Financial Distress Dengan Menggunakan Model Altman Z-Score Modifikasi1995.Diponegoro Journal Of Management.Volume 1, Nomor 1, Halaman 1/11

Mochamad Irfan dan Tri Yuniati.2014.Analisis Financial Distress Dengan Pendekatan Altman Z"'-Score Untuk Memprediksi Kebangkrutan Perusahaan Telekomunikasi. Jurnal Ilmu \& Riset Manajemen Vol. 3 No. 1 (2014)

Munawir. 2010. Analisis Laporan Keuangan. Cetakan Kelima Belas. Yogyakarta: Liberty Yogyakarta.

Nazir, Moh. 2005. Metode Penelitian. Cetakan Pertama. Penerbit Ghalia Indonesia. Jakarta.

Patricia.2010.Penyebab, Dampak dan Prediksi dari Financial Distress serta Solusi untuk Mengatasi Financial Distress. Jurnal Akuntansi Kontemporer. Vol. 2 No. 2, Hal: 191-205

Ramadhani, Ayu Suci dan Niki Lukviarman. 2009. 
JURNAL PLANS

Penelitian Ilmu Manajemen \& Bisnis

ISSN: 1978-7057

E-ISSN: 2527-306X

Perbandingan Analisis Prediksi Kebangkrutan Menggunakan Model Altman Pertama, Altman Revisi, dan Altman Modifikasi dengan Ukuran dan Umur Perusahaan Sebagai Variabel Penjelas (Studi pada Perusahaan Manufaktur yang Terdaftar di Bursa Efek Indonesia). Jurnal Siasat Bisnis, Volume 13, Nomor 1, pp.15-28.

Sekaran, Uma. 2009. Metodologi Penelitian untuk Bisnis. Ed.4. Jakarta: Salemba Empat

Sugiyono. 2010. Metode Penelitian Kuantitatif Kualitatif dan $R \& D$. Bandung: Alfabeta.

Supardi dan

Sri

Mastuti.2003.Validitas

Penggunaan Z-Score Altman untuk Menilai Kebangkrutan pada Perusahaan Perbankan Go Publik di Bursa Efek Jakarta.Dalam Kompak No. 7. Januari - April, hal.10
Syafri Harahap, Sofyan. 2013. Analisis Kritis Atas Laporan Keuangan. Raja Grafindo Persada: Yogyakarta.

Wild, John J., K. R. Subramanyam, dan Robert F. Halsey. 2004. Financial Statement Analysis.The McGraw-Hill Companies Inc., diterjemahkan oleh Yanivi S. Bachtiar dan S. Nurwahyu Harahap. 2005. Analisis Laporan Keuangan. Jakarta: Salemba Empat

Whitaker, R.B.1999.The Early Stages of Financial Distress. Journal of Economicsand Finance Vol 23: $123-133$

Yuliastary, Etta Citrawati dan Made ede Wirakusuma.2014.Analisis Financial Distress Dengan Metode Z-Score, Springate, Zmijewski.E-Jurnal Akuntansi Universitas Udayana.ISSN: 2302-8556 